Огляди літератури, оригінальні дослідження, погляд на проблему, випадок з практики, короткі повідомлення уДК 616-009.12

DOI 10.11603/1811-2471.2020.v.i2.11341

\title{
ХРОНІЧНИЙ БІЛЬ ПРИ ХВОРОБІ ПАРКІНСОНА: РЕЗУЛЬТАТИ АНАЛІЗУ РЕГІОНАЛЬНОГО PEECTPY
}

\author{
ㅇ. В. Хубетова
}

\section{Одеська обласна клінічна лікарня, Одеса}

РЕЗЮМЕ. Метою дослідження була оцінка поширеності хронічного болю у хворих на хворобу Паркінсона (ХП) в Одеській області.

Матеріал і методи. Дослідження виконано на базі Обласної клінічної лікарні (м. Одеса). Проведений ретро-

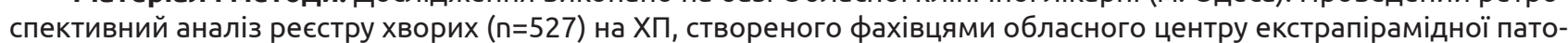
логії. Додатково проведене проспективне обстеження 50 хворих у віці 50-60 років з верифікованим діагнозом ХП. Оцінювали моторні та немоторні прояви захворювання, особливості його перебігу, приділяючи особливу увагу проявам больового синдрому в залежності від застосованої терапії.

Результати. Сумарна оцінка за шкалами KPPQ склала, в середньому, $(26,9 \pm 2,0)$ балів. При цьому найвища ін-

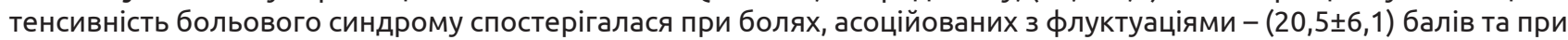
нічних болях - $(13,5 \pm 2,0)$ балів. При орофасціальному болю його інтенсивність складала $(8,4 \pm 3,3)$ балів, а при корінцевому болю - $(7,5 \pm 2,7)$ балів. При набряках та ознаках запалення інтенсивність болю відповідала $(9,9 \pm 2,4) 6 а-$ лів. При оцінці впливу лікування на вираження больового синдрому при проспективному спостереженні встановлено, що інтенсивність болю за ВАШ зменшується через 3 місяці на 30-35 \%.

Висновки. У 121 (23,0 \%) пацієнта наявний больовий синдром різного ступеня вираженості. Найчастіше зустрічалися нічний біль (21,5 \%) та м'язово-скелетний біль, як ізольовані $(23,1$ \%) так і в різних комбінаціях. Біль 3 флуктуаціями різної локалізації виявлено у 27 (5,1 \% від загальної численності осіб у реєстрі (n=527)). Нічний біль зустрічався у 94 (17,8 \%) випадків, орофасціальний - у 29 (5,5%). Біль, пов'язаний із набряками та ознаками запалення, був у 58 (11,0\%), корінцевий біль - у 37 (7,0\%). При застосуванні комбінованої протипаркінсонічної терапії інтенсивність болю за ВАШ зменшується через 3 місяці на 30-35\%.

КЛючовІ СлОВА: хвороба Паркінсона; хронічний біль; діагностика.

Вступ. Хвороба Паркінсона (ХП) - хронічне прогресуюче нейродегенеративне захворювання, яке характеризується ураженням нігростріальної дофамінергічної системи $[1,2]$. İ̈̈ поширеність у загальній популяції становить 0,1-0,3 \% [3], зростаючи у осіб старше 65 років до $2 \%[1,3]$.

Основними клінічними проявами ХП $\epsilon$ тремор, ригідність, акінезія або брадикінезія, гіпокінезія та постуральна нестабільність. Крім рухових порушень, у хворих на ХП нерідко реєструються немоторні симптоми, в тому числі вегетативні, зокрема гіпергідроз, ортостатична гіпотензія, сексуально-сечова дисфункція, зміни терморегуляції, порушення серцево-судинної системи, периферійні набряки, мідріаз, порушення сну, нервово-психічні проблеми у вигляді апатії, втоми, ангедонії, депресії, тривожності, панічних атак, деменції, рідше психотичні стани $[4,5]$. У багатьох пацієнтів виникають різноманітні сенсорні порушення, в тому числі синдром неспокійних ніг, оніміння, парестезії, зорові порушення та біль [4]. Біль спостерігається приблизно у 30-50 \% хворих на ХП, проте деякі автори вказують на більш високу частоту реєстрації болю-до $85 \%[4,6,7]$. Біль може з'явитися в будь-який час впродовж захворювання, а в окремих випадках він турбує пацієнта до встановлення діагнозу [6]. Досі немає консенсусу щодо класифікації та механізмів альгогенезу при ХП $[8,9]$.
Мета - оцінка поширеності хронічного болю у хворих на ХП в Одеській області.

Матеріал і методи дослідження. Дослідження проведене на базі Обласної клінічної лікарні (м. Одеса). Проведений ретроспективний аналіз реєстру хворих на ХП, створеного фахівцями обласного центру екстрапірамідної патології. На момент написання роботи в реєстрі було 527 пацієнтів.

Додатково проведене проспективне обстеження 50 хворих у віці 50-60 років із верифікованим діагнозом ХП. Оцінювали моторні та немоторні прояви захворювання, особливості його перебігу, приділяючи особливу увагу проявам больового синдрому в залежності від застосованої терапії.

Усі пацієнти проходили опитування за The King's Parkinson's Disease Pain Questionnaire (KPPQ) [10]. Оцінювали частоту хронічного болю, кваліфікуючи його види за класифікацією О. С. Левіна та С. О. Махнева [11]. Додатково оцінювали загальну суму балів за клінічною шкалою болю (КШБ) [12].

Статистичну обробку одержаних даних проводили за допомогою програмного комплексу TIBCO Statistica 13.5 (США) [13].

Результати й обговорення. При аналізі поширеності больового синдрому у хворих на ХП, які увійшли до регіонального реєстру, встановлено, що у 121 (23,0 \%) пацієнта мав місце больовий синдром різного ступеня вираження (табл. 1). 
Огляди літератури, оригінальні дослідження, погляд на проблему, випадок з практики, короткі повідомлення Таблиця 1 Результати опитування за KPPQ (дані регіонального реєстру)

\begin{tabular}{|c|c|c|}
\hline Особливості больового синдрому & A6c. & $\%$ \\
\hline Нічний, м'язово-скелетний & 17 & 14,0 \\
\hline М'язово-скелетний (ізольований) & 28 & 23,1 \\
\hline Хронічний, м'язово-скелетний & 5 & 4,1 \\
\hline Нічний & 26 & 21,5 \\
\hline М'язово-скелетний, корінцевий, орофасціальний & 1 & 0,8 \\
\hline Змішаний & 7 & 5,8 \\
\hline М'язово-скелетний; зміна кольору, набряк & 4 & 3,3 \\
\hline М'язово-скелетний, корінцевий & 3 & 2,5 \\
\hline М'язово-скелетний, нічний біль, біль, пов'язаний з флуктуаціями & 3 & 2,5 \\
\hline Біль, пов'язаний з флуктуаціями; зміна кольору, набряк & 2 & 1,7 \\
\hline Хронічний, м'язово-скелетний, нічний & 2 & 1,7 \\
\hline Біль, пов'язаний з флуктуаціями, нічний & 3 & 2,5 \\
\hline М'язово-скелетний; нічний; зміна кольору, набряк & 1 & 0,8 \\
\hline Нічний орофасціальний & 2 & 1,7 \\
\hline М'язово-скелетний, біль, пов'язаний із флуктуаціями & 2 & 1,7 \\
\hline Нічний корінцевий & 1 & 0,8 \\
\hline Біль, пов'язаний з флуктуаціями, змішаний & 1 & 0,8 \\
\hline Нічний, зміна кольору, набряк & 1 & 0,8 \\
\hline Зміна кольору, набряк & 2 & 1,7 \\
\hline Орофасціальний; м'язово-скелетний & 3 & 2,5 \\
\hline Орофасціальний, м'язово-скелетний, нічний & 1 & 0,8 \\
\hline Хронічний & 1 & 0,8 \\
\hline Біль, пов'язаний із флуктуаціями & 2 & 1,7 \\
\hline Біль, пов'язаний із флуктуаціями, орофасціальний біль & 1 & 0,8 \\
\hline М'язово-скелетний біль, біль центрального характеру & 1 & 0,8 \\
\hline Орофасціальний & 1 & 0,8 \\
\hline ВСьОГО & 121 & 100,0 \\
\hline
\end{tabular}

Найчастіше зустрічалися нічний $(21,5 \%)$ та м'язово-скелетний біль, як ізольований $(23,1 \%)$, так і в різних комбінаціях. В цілому біль з флуктуаціями різної локалізації зустрічався у 27 (5,1% від загального числа осіб у реєстрі $(n=527))$. Нічний біль зустрічався у 94 (17,8 \%) випадках, орофасціальний - у 29 (5,5 \%). Біль, пов'язаний із набряками та ознаками запалення, був у 58 (11,0 \%), корінцевий біль - у 37 (7,0\%).

Найчастіше хворі описували біль як своєрідні відчуття без чіткої локалізації або болю в проксимальних відділах кінцівок, зазвичай на боці більш виражених симптомів паркінсонізму. Біль частіше мав глибинний, тупий, ниючий, стискаючий або сверблячий характер з локалізацією в шиї, спині та кінцівках. В окремих випадках біль мав яскраве вегетативне забарвлення, хворі описували його як «пекучі», «колючі» відчуття, які виникали в різних ділянках тіла, в тому числі в порожнині рота і в ділянці геніталій. Найчастішими словамидескрипторами, якими пацієнти описують біль, були: «тупі», «гризучі» і «обпалюючі». Рідше хворі описували відчуття поколювання й оніміння в дистальних відділах кінцівок.
Деякі автори повідомляють про наявність прямого зв'язку між виразністю болю і стадією хвороби Паркінсона, починаючи з дебюту захворювання, коли больовий синдром виникає на тому ж боці, де в подальшому маніфестують моторні прояви ХП. Цікаво, що при симультанному виникненні болю та екстрапірамідної рухової симптоматики або на фоні вже сталої симптоматики ХП, його локалізація також збігається $[6,8$, $11,14]$.

Дані щодо вираження болю (рис. 1) були вельми варіабельні. Загалом інтенсивність болю корелювала із тривалістю захворювання $(r=0,59)$ та стадією ХП $(r=0,64)$.

Сумарна оцінка за шкалами KPPQ склала в середньому $(26,9 \pm 2,0)$ балів. При цьому найвища інтенсивність больового синдрому спостерігалася при болю, асоційованому з флуктуаціями $(20,5 \pm 6,1)$ балів, та при нічному болю - $(13,5 \pm$ $2,0)$ балів. Натомість, при орофасціальному болю його інтенсивність складала $(8,4 \pm 3,3)$ балів, а при корінцевому болю - $(7,5 \pm 2,7)$ балів. При набряках та ознаках запалення інтенсивність болю відповідала $(9,9 \pm 2,4)$ балів. 
Огляди літератури, оригінальні дослідження, погляд на проблему, випадок з практики, короткі повідомлення Box \& Whisker Plot



Рис. 1. Вираження больового синдрому у пацієнтів з хворобою Паркінсона.

При оцінці впливу лікування на вираження больового синдрому при проспективному спостереженні встановлено, що інтенсивність болю за ВАШ зменшується через 3 місяці на 30-35 \%. Наше спостереження збігається з даними інших дослідників, які зазначають, що корекція симптомів паркінсонізму і моторних флуктуацій зі збільшенням добової дози і кратності прийому леводопи приводить до зменшення болю в більшості хворих. Найкраща відповідь на збільшення дози леводопи встановлена при больових синдромах, пов'язаних з флуктуаціями, локальним або реґіонарним підвищенням м'язового тонусу, а також при больовому синдромі центрального ґенезу.

ХП як мультифокальне нейродегенеративне прогресуюче захворювання може впливати на ноцицепцію на декількох рівнях, починаючи від передачі болю від периферійних структур до вищих центрів, які забезпечують перцепцію та інтерпретацію больових імпульсів. У пацієнтів з ХП зменшується кількість вільних та інкапсульованих нервових закінчень (тільця Мейснера), що призводить до периферійної деаференціації. Починаючи з ранніх стадії ХП дегенеративні зміни можуть відбуватися і в спинному мозку. Певні втрати нейронів спостерігаються в постеромаргінальному ядрі (І пластинка за B. Rexed) заднього рогу спинного мозку $[6,14,15]$.

Braak H. et al. (2003) поділив хворобу на 6 періодів [16]. Зміни, характерні для передмоторно- го періоду, починаються в нюховій цибулині і поступово просуваються до нижньої ділянки стовбура мозку (включаючи довгастий мозок та міст) 3 накопиченням тілець Леві (1 та 2 стадії). У наступні симптоматичні періоди патологічні зміни відбуваються в середньому мозку, включаючи substantia nigra (стадія 3), мезокортексу (стадія 4) i, нарешті, неокортексу (стадія 5-6) [16]. Ноцицептивна інформація не може передаватися безпосередньо від спинного мозку до вищих центрів [15, 16], оскільки він модулюється низхідними шляхами, які залучають різні ядра стовбура. Деякі з цих ядер уражаються вже на початку ХП [16-18]. Ця класифікація на 6 періодів може бути корисною для розуміння змін, які відбуваються в анатомічній структурі болю, пов'язаного з вищими центрами на різних етапах перебігу ХП.

Таким чином, зменшення інтенсивності больового синдрому при застосуванні лікарських засобів з допамінергічною активністю $є$ відображенням суттєвих змін аферентації больових імпульсів та їх перцепції у структурах ЦНС при ХП.

Висновки. 1. У 121 (23,0 \%) пацієнта наявний больовий синдром різного ступеня вираження.

2. Найчастіше зустрічалися нічний $(21,5 \%)$ та м'язово-скелетний біль, як ізольований $(23,1$ \%), так і в різних комбінаціях.

3. Біль з флуктуаціями різної локалізації зустрічався у 27 пацієнтів (5,1% від загальної чисельності осіб у реєстрі $(n=527))$. 
Огляди літератури, оригінальні дослідження, погляд на проблему, випадок з практики, короткі повідомлення

4. Нічний біль зустрічався у 94 (17,8 \%) випадках, орофасціальний-у 29 (5,5%). Біль, пов'язаний із набряками та ознаками запалення, був у 58 (11,0\%), корінцевий біль - у 37 (7,0\%).
5. При застосуванні комбінованої протипаркінсонічної терапії інтенсивність болю за ВАШ через 3 місяці зменшується на 30-35 \%.

\section{ЛІТЕРАТУРА}

1. Armstrong M. J. Diagnosis and treatment of Parkinson disease: A review / M. J. Armstrong, M. S. Okun // JAMA. - 2020. - Vol. 323 (6). - P. 548-560.

2. Fanning S. Parkinson's disease: proteinopathy or lipidopathy? / S. Fanning, D. Selkoe, U. Dettmer // NPJ Parkinson's Dis. - 2020. - No. 6. - P. 3.

3. Ascherio A. The epidemiology of Parkinson's disease: risk factors and prevention / A. Ascherio, M. A. Schwarzschild // Lancet Neurol. - 2016. - Vol. 15 (12). - P. 1257-1272.

4. Sahli H. Non-motor symptoms of Parkinson disease and their management / H. Sahli, L. Seddik, P. Rémy // Rev. Prat. - 2018. - Vol. 68 (5). - P. 508-512.

5. Возможности сохранения трудоспособности у пациентов с болезнью Паркинсона / О. А. Ганькина, Е. Е. Васенина, Д. Д. Похабов [и др.] // Журнал неврологии и психиатрии им. С. С. Корсакова. - 2018. - Т. 118, № 6-2. С. 95-98.

6. Parkinson disease and musculoskeletal pain: an 8-year population-based cohort study /W. H. Lien, W. C. Lien, T. S. Kuan [et al.] // Pain. - 2017. - Vol. 158 (7). P. 1234-1240.

7. Integrated approach for pain management in Parkinson disease / C. Geroin, M. Gandolfi, V. Bruno [et al.] // Curr. Neurol. Neurosci. Rep. - 2016. - Vol. 16 (4). - P. 2.

8. Pain in Parkinson disease: a review of the literature / A. Fil, R. Cano-de-la-Cuerda, E. Muñoz-Hellín [et al.] / Parkinsonism Relat. Disord. - 2013. - Vol. 19 (3). P. 285-294.

9. Camacho-Conde J. A. The phenomenology of pain in Parkinson's disease / J. A. Camacho-Conde, V. M. CamposArillo // Korean J. Pain. - 2020. - Vol. 33 (1). - P. 90-96.

10. First comprehensive tool for screening pain in Parkinson's disease: the King's Parkinson's Disease Pain Questionnaire / P. Martinez-Martin, A. M. Rizos, J. Wetmore [et al.] // Eur. J. Neurol. - 2018. - Vol. 25 (10). P. $1255-1261$.

11. Левин О. С. Болезнь Паркинсона / О. С. Левин, Н. В. Федорова. - 3-е изд. - М.: МЕДпресс-информ, 2012. - 352 C.

12. Assessment of psychological pain in clinical and non-clinical samples: A preliminary investigation using the psychic pain scale / K. C. Lewis, E. W. Good, J. G. Tillman, C. J. Hopwood // Arch Suicide Res. - 2020. - P. 1-18.

13. Халафян A. A. Statistica 6. Статистический анализ данных / А. А. Халафян. - М. : Бином-Пресс, 2007. 512 c.

14. Mood, side of motor symptom onset and pain complaints in Parkinson's disease / P. McNamara, K. Stavitsky, E. Harris [et al.] // Int. J. Geriatr. Psychiatry. - 2010. Vol. 25 (5). - P. 519-524.

15. Lee G. I. Pain: Pathways and physiology / G. I. Lee, M. W. Neumeister // Clin. Plast. Surg. - 2020. - Vol. 47 (2). P. $173-180$

16. Idiopathic Parkinson's disease: possible routes by which vulnerable neuronal types may be subject to neuroinvasion by an unknown pathogen / H. Braak, U. Rüb, W. P. Gai, K. Del Tredici // J. Neural Transm. (Vienna). 2003. - Vol. 110 (5). - P. 517-536.

17. Most cases with Lewy pathology in a populationbased cohort adhere to the Braak progression pattern but 'failure to fit' is highly dependent on staging system applied / D. G. Coughlin, H. Petrovitch, L. R. White [et al.] // Parkinsonism Relat. Disord. - 2019. - Vol. 64. P. 124-131.

18. Braak H. Neuropathological staging of brain pathology in sporadic Parkinson's disease: Separating the wheat from the chaff / H. Braak, K. Del Tredici // J. Parkinsons Dis. - 2017. - Vol. 7 (s1). - P. S71-S85.

\section{REFERENCES}

1. Armstrong, M.J., \& Okun, M.S. (2020). Diagnosis and treatment of Parkinson disease: A review. JAMA, 323 (6), 548-560.

2. Fanning, S., Selkoe, D., \& Dettmer, U. (2020). Parkinsons disease: proteinopathy or lipidopathy? NPJ Parkinson's Dis., 6, 3.

3. Ascherio, A., \& Schwarzschild, M.A. (2016). The epidemiology of Parkinson's disease: risk factors and prevention. Lancet Neurol., 15 (12), 1257-1272.

4. Sahli, H., Seddik, L., \& Rémy, P. (2018). Non-motor symptoms of Parkinson disease and their management. Rev. Prat., 68 (5), 508-512.
5. Gankina, O.A., Vasenina, E.E., Pokhabov, D.D., Voronov, D.B., Zhukova, Y.A., Baytimerov, A.R., ..., \& Levin, O.S. (2018). Vozmozhnosti sokhraneniya trudosposobnosti u patsiyentov s boleznyu Parkinsona [Possibilities of preserving working capacity in patients with Parkinson's disease]. Zhurnal nevrologii i psikhiatrii im. S.S. Korsakova Journal of Neurology and Psychiatry by S.S. Korsakov, 118, 6-2, 95-98 [in Russian].

6. Lien, W.H., Lien, W.C., Kuan, T.S., Wu, S.T., Chen, Y.T., \& Chiu CJ. (2017). Parkinson disease and musculoskeletal pain: an 8-year population-based cohort study. Pain, 158 (7), 1234-1240. 
Огляди літератури, оригінальні дослідження, погляд на проблему, випадок з практики, короткі повідомлення

7. Geroin, C., Gandolfi, M., Bruno, V., Smania, N., \& Tinazzi, M. (2016). Integrated approach for pain management in Parkinson disease. Curr. Neurol. Neurosci. Rep., 16 (4), 2.

8. Fil, A., Cano-de-la-Cuerda, R., Muñoz-Hellín, E., Vela, L., Ramiro-González, M., \& Fernández-de-Las-Peñas, C. (2013). Pain in Parkinson disease: a review of the literature. Parkinsonism Relat. Disord., 19 (3), 285-294.

9. Camacho-Conde, J.A., \& Campos-Arillo, V.M. (2020). The phenomenology of pain in Parkinson's disease. Korean J. Pain., 33 (1), 90-96.

10. Martinez-Martin, P., Rizos, A.M., Wetmore, J., Antonini, A., Odin, P., Pal, S., ..., \& Chaudhuri, K.R. (2018). First comprehensive tool for screening pain in Parkinson's disease: the King's Parkinson's Disease Pain Questionnaire. Eur. J. Neurol., 25 (10), 1255-1261.

11. Levin, O.S., \& Fedorova, N.V. (2012). Bolezn Parkinsona [Parkinson's disease. 3rd ed]. Moscow: MEDpress-inform [in Russian].

12. Lewis, K.C., Good, E.W., Tillman, J.G., \& Hopwood, C.J. (2020). Assessment of psychological pain in clinical and non-clinical samples: A preliminary investigation using the psychic pain scale. Arch. Suicide Res., 1-18.

13. Khalafyan, A.A. (2007). Statistica 6. Statisticheskiy analiz dannykh [Statistica 6. Statistical data analysis]. Moscow: Binom-Press [in Russian].

14. McNamara, P., Stavitsky, K., Harris, E., Szent-Imrey, O., \& Durso, R. (2010). Mood, side of motor symptom onset and pain complaints in Parkinson's disease. Int. J. Geriatr. Psychiatry, 25 (5), 519-524.

15. Lee, G.I., \& Neumeister, M.W. (2020). Pain: Pathways and physiology. Clin. Plast. Surg., 47 (2), 173-180.

16. Braak, H., Rüb, U., Gai, W.P., \& Del Tredici, K. (2003). Idiopathic Parkinson's disease: possible routes by which vulnerable neuronal types may be subject to neuroinvasion by an unknown pathogen. J. Neural. Transm. (Vienna), 110 (5), 517-536.

17. Coughlin, D.G., Petrovitch, H., White, L.R., Noorigian, J., Masaki, K.H., Ross, G.W., \& Duda, J.E. (2019). Most cases with Lewy pathology in a population-based cohort adhere to the Braak progression pattern but 'failure to fit' is highly dependent on staging system applied. Parkinsonism Relat. Disord., 64, 124-131.

18.Braak,H., \&DelTredici, K. (2017). Neuropathological staging of brain pathology in sporadic Parkinson's disease: Separating the wheat from the chaff. J. Parkinsons Dis., 7 (s1), S71-S85.

\section{ХРОНИЧЕСКАЯ БОЛЬ ПРИ БОЛЕЗНИ ПАРКИНСОНА: РЕЗУЛЬТАТЫ АНАЛИЗА РЕГИОНАЛЬНОГО РЕЕСТРА}

○И. В. Хубетова

\section{Одесская областная клиническая больница, г. Одесса}

РЕЗюМЕ. Целью исследования была оценка распространенности хронической боли у больных болезнью Паркинсона в Одесской области.

Материал и методы. Исследование проведено на базе Областной клинической больницы (г. Одесса). Проведен ретроспективный анализ реестра больных ( $n=527)$ ХП, созданного специалистами областного центра экстрапирамидной патологии. Дополнительно проведено проспективное обследование 50 больных в возрасте 50-60 лет с верифицированным диагнозом ХП. Оценивали моторные и немоторные проявления заболевания, особенности его течения, уделяя особое внимание проявлениям болевого синдрома в зависимости от примененной терапии.

Результаты. Суммарная оценка по шкалам KPPQ составила, в среднем, $(26,9 \pm 2,0)$ баллов. При этом самая высокая интенсивность болевого синдрома наблюдалась при боли, ассоциированной с флуктуациями $(20,5 \pm 6,1)$ баллов и при ночной боли - $(13,5 \pm 2,0)$ баллов. При орофасциальной боли ее интенсивность составляла $(8,4 \pm 3,3)$ баллов, а при корешковой боли - $(7,5 \pm 2,7)$ баллов. При отеках и признаках воспаления интенсивность боли отвечала $(9,9 \pm 2,4)$ баллов. При оценке влияния лечения на выраженность болевого синдрома при проспективном наблюдении установлено, что интенсивность боли по ВАШ уменьшается через 3 месяца на 30-35 \%.

Выводы. У 121 (23,0 \%) пациента имеет место болевой синдром различной степени выраженности. Наиболее часто встречалась ночная (21,5 \%) и мышечно-скелетная боль, как изолированно $(23,1$ \%), так и в различных комбинациях. Боль с флуктуациями различной локализации встречалась у 27 пациентов $(5,1$ \% от общей численности лиц в реестре ( $n=527))$. Ночная боль встречалась у $94(17,8 \%)$ больных, орофасциальная - у 29 (5,5\%). Боль, связанная с отеками и признаками воспаления, была у 58 (11,0\%), корешковые боли -у 37 (7,0\%) пациентов. При применении комбинированной противопаркинсонической терапии интенсивность боли по ВАШ уменьшается через 3 месяца на 30-35\%

КЛЮЧЕВЫЕ СЛОВА: болезнь Паркинсона; хроническая боль; диагностика. 


\section{Odesa Regional Clinical Hospital}

SUMMARY. The aim - was to assess the prevalence of chronic pain in patients with Parkinson's disease (PD) in Odesa region

Material and Methods. The study was conducted on the basis of the Regional Clinical Hospital (Odesa). A retrospective analysis of the registry of patients $(n=527)$ of PD, created by specialists of the regional center of extrapyramidal pathology. Additionally, a prospective examination of 50 patients aged 50-60 years with a verified diagnosis of PD was carried out. We evaluated the motor and non-motor manifestations of the disease, especially its course, paying particular attention to the manifestations of pain, depending on the therapy used.

Results. The total score for KPPQ flares averaged (26.9 2.0$)$ points. The highest intensity of the pain syndrome was observed for pain associated with fluctuations - (20.5 \pm 6.1$)$ points and for night pain - (13.5 \pm 2.0$)$ points. With orofascial pain, its intensity was $(8.4 \pm 3.3)$ points, and with radicular pain $-(7.5 \pm 2.7)$ points. With edema and signs of inflammation, the intensity of the pain responded $(9.9 \pm 2.4)$ points. When assessing the effect of treatment on the severity of pain during prospective observation, it was found that the intensity of pain according to VAS decreases after 3 months by $30-35 \%$.

Conclusions. In 121 (23.0\%) patients, pain syndrome of varying severity occurs. The most common were night pains (21.5\%) and musculoskeletal pains, both isolated (23.1\%) and in various combinations. Pain with fluctuations of various localization occurred in 27 (5.1\% of the total number of persons in the registry $(n=527))$. Night pains occurred in 94 (17.8\%) cases, orofascial - in 29 (5.5\%). Pain associated with edema and signs of inflammation were observed in 58 (11.0\%), radicular pain - in 37 (7.0\%). When using combined antiparkinsonian therapy, the intensity of pain according to VAS decreases after 3 months by 30-35\%

KEY WORDS: Parkinson's disease; chronic pain; diagnosis.

Отримано 5.06.2020 